\title{
STRATEGI KOMUNIKASI LSM LINGKUNGAN DI INDONESIA DALAM MENDORONG LAHIRNYA UNDANG-UNDANG PERUBAHAN IKLIM
}

\author{
Nailil Maghfiroh $^{1}$, Yudi LA Salampessy ${ }^{2}$ \\ ${ }^{1}$ BPP Kecamatan Purwosari Kabupaten Pasuruan \\ ${ }^{2}$ Dosen Program Pascasarjana Universitas Sultan Ageng Tirtayasa \\ Email: ysalampessy@gmail.com
}

\begin{abstract}
Abstrak
Isu perubahan iklim di Indonesia harus segera direspon bukan lagi dengan penyediaan teknologi, tetapi direspon secara politik dengan komitmen untuk melaksanakannya. Akan tetapi pemerintahan dan DPR belum menjadikan legislasi Undang-Undang Perubahan Iklim sebagai prioritas. Untuk itu beberapa LSM Lingkungan menjalin komunikasi politik untuk mendorong lahirnya UU tersebut. Artikel menganalisis strategi komunikasi yang diterapkan oleh LSM Lingkungan dalam penyebaran informasi dan mendorong pengesahan UU terkait perubahan iklim. Kajian disusun sebagai studi literatur dengan analisis deskriptif. Disimpulkan bahwa LSM Lingkungan mengkombinasikan strategi komunikasi pembangunan berdasarkan media yang dipakai dan strategi partisipatori. Pemanfaatan saluran komunikasi interpersonal dan massa bertujuan untuk mengoptimalkan persuasi atas pentingnya perilaku adaptif, serta membuka ruang publik untuk partisipasi anggota masyarakat. Belum disahkannya UU Perubahan Iklim mengindikasikan belum tercapainya efek yang diharapkan dari komunikasi politik yang dijalin.
\end{abstract}

Kata Kunci: Perubahan iklim, LSM, strategi komunikasi

\section{PENDAHULUAN \\ Latar Belakang}

Menurut laporan Intergovernmental

Panel on Climate Change (IPCC) tahun 2013, kenaikan temperatur di kawasan Asia Tenggara sejak tahun 1901 tercatat ada pada kisaran 0,4 $1^{\circ} \mathrm{C}$. Untuk jangka menengah (2046 - 2065) diperkirakan ada pada rentang $1,5-2^{\circ} \mathrm{C}$, sedangkan untuk jangka panjang (2081 - 2100) akan berada di rentang $2-4^{\circ} \mathrm{C}$ yang akan menyebar ke seluruh daratan secara merata. Suhu tertinggi di siang hari akan mencapai 3 $4^{\circ} \mathrm{C}$ lebih tinggi dari temperatur rata-rata saat ini. Curah hujan diperkirakan akan meningkat di Indonesia dan Papua Nugini. Secara keseluruhan, curah hujan tahunan diperkirakan akan meningkat, kecuali di wilayah bagian Barat Daya Indonesia. Dengan demikian dampak perubahan iklim di kawasan Asia Tenggara, termasuk di Indonesia, diperkirakan akan meningkatkan ancaman terhadap ketahanan pangan, kesehatan manusia, ketersediaan air, keragaman hayati, dan kenaikan muka air laut (ICAN 2013).

Kondisi iklim hasil pengamatan maupun perkiraan tersebut menegaskan keharusan dilakukannya upaya-upaya yang dapat meminimalisir dampak negatif perubahan iklim di Indonesia. Utamanya karena dampak perubahan iklim yang mencakup kenaikan muka dan suhu air laut, peningkatan curah hujan, peningkatan evaporasi di musim panas, dan peningkatan intensitas badai tropis menyebabkan kerugian di berbagai aspek kehidupan (Arundhati dkk 2014). Dengan demikian semakin meningkatnya frekuensi dan 
intensitas terjadinya bencana alam seperti kekeringan akibat kemarau berkepanjangan, banjir bandang akibat musim hujan berkepanjangan atau musim hujan ekstrim pendek, tanah longsor, penyebaran hama dan penyakit dan lain sebagainya belakangan ini merupakan indikasi keterlambatan pemerintah dalam merespon isu-isu perubahan iklim global.

Keterlambatan diperkuat oleh kenyataan bahwa perubahan iklim baru menjadi isu penting di kalangan ilmuan dan pemerhati lingkungan di Indonesia. Isu ini relatif masih baru dan kompleks untuk dipahami bagi kebanyakan anggota masyarakat. Hal ini karena belum banyak anggota masyarakat yang mendapatkan informasi perubahan iklim atau dengan mudah memahaminya sehingga mengetahui bahwa sebagian gangguan alam yang sering dihadapi merupakan wujud dari dampak negatif perubahan iklim yang sedang berlangsung, yang disebabkan oleh manusia, dan bisa menjadi ancaman utama kehidupan dimasa datang. Selain itu, isu-isu perubahan iklim juga relatif belum menjadi prioritas dalam agenda partai-partai dan para pemimpin politik yang merupakan penentu kebijakan, meskipun pertarungan dan pemilihan legislatif dan presiden banyak mendominasi kehidupan politik di Indonesia dalam satu tahun terakhir ini. Bahkan, Dewan Nasional Perubahan Iklim (DNPI) yang telah dibentuk hampir sama sekali belum mampu meramaikan isu-isu politik yang berkembang selama musim pemilu dengan isu perubahan iklim yang sangat penting bagi keberhasilan dan keberlanjutan pembangunan nasional.

Mengingat dampak perubahan iklim dapat mengancam kesejahteraan hidup anggota masyarakat, dan ketidakmampuan beradaptasi akan semakin memperlambat proses pencapaian tujuan pembangunan, maka sudah saatnya pemerintah menjadikan adaptasi perubahan iklim sebagai salah satu komponen yang terintegrasi dalam setiap kebijakan pembangunan nasional. Dengan demikian isu ini harus direspon bukan lagi dengan pilihan dan penyediaan teknologi mitigasi dan adaptasi perubahan iklim karena saat ini sudah tersedia di pasar, melainkan segera direspon secara politik dengan komitmen untuk melaksanakannya. Akan tetapi sampai saat ini pemerintahan Joko Widodo dan DPR yang memiliki kewenangan dalam membuat legislasi belum menjadikan Undang-Undang Perubahan
Iklim sebagai prioritas dalam proses legislasi di parlemen.

Bernauer (2013) menyatakan bahwa dua hambatan utama dalam politik iklim adalah pengabaian yang sangat dari keuntungan di masa depan dari mengadopsi secara ketat kebijakan iklim pada hari ini, dan distribusi dari biaya dan keuntungan dari kebijakan iklim dalam dan lintas negara. Dalam konteks ini, opini publik memainkan sebuah peran krusial dalam politik iklim. Tidak mengherankan jika beberapa LSM Lingkungan di Indonesia yang perduli pada keberhasilan dan keberlangsungan pembangunan seperti Walhi, FNF, Center for Dialogue and Cooperation among Civilisations (CDCC), Down to Earth (DtE) dan yang lainnya kemudian terus mendorong lahirnya UU Perubahan Iklim sebelum isu ini semakin menjadi kurang sexy dibandingkan isu-isu politik lainnya seperti struktur kabinet, koalisi parlemen, skandal korupsi, atau memang masih sulit dicerna oleh banyak kalangan.

Melalui komunikasi kepada para pihak, LSM-LSM Lingkungan terus mengaliran informasi iklim dan fenomena perubahannya sehingga mendorong tetap terjalinnya komunikasi perubahan iklim. Utamanya kepada para penyusun kebijakan pembangunan agar dukungan pemerintah dan politisi atas pengesahan UU Perubahan Iklim tetap terjaga. Efektivitas upaya ini tentu sangat bergantung pada strategi komunikasi yang diterapkan oleh kalangan LSM Lingkungan, seperti yang ditegaskan oleh McPhail (2009) bahwa LSM tidak akan dapat bertahan tanpa strategi komunikasi yang tepat.

\section{Tujuan}

Artikel ini bermaksud menganalisis strategi komunikasi yang diterapkan oleh LSM Lingkungan di Indonesia dalam penyebaran informasi dan mendorong pengesahan UU terkait perubahan iklim global.

\section{LANDASAN TEORI DAN KONSEPTUAL}

Nimmo (1999) menjelaskan konsep komunikasi politik dengan menggunakan model Laswell yang mendefinisikan proses komunikasi dengan kalimat "who says what in which channel to whom with what effect". Dengan demikian dapat diketahui bahwa komunikasi memiliki unsur-unsur sumber, pesan, saluran, penerima, dan efek. Selanjutnya dijelaskan bahwa saluran komunikasi politik 
terdiri dari saluran komunikasi interpersonal, saluran komunikasi massa, dan saluran komunikasi organisasi.

Beranjak dari pemikiran Innis yang fokus pada dua saluran komunikasi utama yaitu komunikasi lisan dan komunikasi tertulis, Nimmo memberikan penekanan pada teori-teori dampak sosial serta dampak politiknya yang meliputi: (1) Teori Perseptual yang menyatakan bahwa setiap media komunikasi mempunyai gramatik, yaitu aturan kerja yang erat hubungannya dengan gabungan indera yang berkaitan dengan penggunaan media oleh seseorang, (2) Teori-Teori Fungsional yang mencakup Teori Persuasi dan Informasi yang menjelaskan bahwa orang memerhatikan media massa karena berusaha menambah pengetahuan dan atau memperoleh bimbingan yang berfungsi mendifusikan informasi dan mempersuasi sehingga komunikasi massa terdiri atas serangkaian sistem yang menyampaikan informasi dengan cara bersambung dan berurutan dari sumber sampai penerima, Teori Permainan yang berargumen bahwa orang berkomunikasi hanyalah demi kesenangan yang diperoleh dari melakukannya, Teori Parasosial yang menyatakan komunikasi massa berfungsi memenuhi kebutuhan manusia akan interaksi sosial, dan Teori Guna dan Kepuasan yang beranggapan bahwa anggota khalayak media adalah peserta aktif dan selektif dalam proses komunikasi.

Berbeda dengan Dan Nimmo yang memosisikan media secara murni sebagai saluran komunikasi yang digunakan oleh aktor politik untuk menyampaikan pesan kepada khalayak, McNair (2003) memosisikan media atau mereka yang bekerja didalamnya sebagai aktor politik itu sendiri yang memiliki peran penting. Media bukan hanya sebagai saluran yang mengirimkan pesan politik kepada publik, tetapi mereka mengubah pesan politik tersebut melalui berbagai proses pembuatan berita dan dan interpretasi. Apa yang diinginkan politisi untuk disampaikan belum tentu sama dengan apa yang dilaporkan oleh media. Selain itu, media membuat pernyataan tentang politik sesuai dengan hak mereka sendiri, dalam bentuk komentar, editorial dan pertanyaan wawancara. Pernyataan ini mungkin memiliki signifikan dampak pada lingkungan politik yang lebih luas.

Strategi komunikasi pembangunan yang telah digunakan selama ini menurut AED dalam Nasution (2002) terdiri dari strategistrategi yang didasarkaan pada media yang dipakai, strategi-strategi desain instruksional, strategi-strategi partisipatori, strategi-strategi pemasaran. Masing-masing strategi mencerminkan suatu rangkaian prioritas tertentu mengenai bagaimana menggunakan komunikasi untuk mencapai kebutuhankebutuhan pembangunan. Kategori ini sendiri tidak dimaksudkan dalam arti yang kaku, karena dalam kenyataannya bukan sedikit program komunikasi pembangunan yang merupakan gabungan dari beberapa strategi.

NGO adalah kepanjangan dari NonGovernmental Organization yang dalam bahasa Indonesia diartikan sebagai Lembaga Swadaya Masyarakat (LSM) yaitu organisasi yang mengkombinasikan tindakan umum dan tujuan kemanusiaan dengan mengedepankan aturanaturan independen dari kontrol pemerintah, tidak mencari keuntungan, bukan kriminal, dan tidak mencari kesempatan pada pemerintahan (tidak menjadi partai politik). Palang Merah, Forum Sosial Dunia, dan Jaringan International untuk Keanekaragaman Budaya merupakan contoh dari LSM (McPhail 2009).

The International Panel on Climate Change atau IPCC (2007) mendefinisikan perubahan iklim sebagai perubahan apa pun terhadap iklim dalam rentang waktu, baik itu karena kegiatan alam atau sebagai akibat dari kegiatan manusia. Perubahan iklim mengacu pada perubahan iklim dari waktu ke waktu, apakah karena variabilitas alam atau sebagai akibat dari aktivitas manusia yang terusmenerus merubah komposisi atmosfer dan tata guna lahan. Perubahan iklim merujuk pada variasi rata-rata kondisi iklim suatu tempat atau pada variabilitasnya yang nyata secara statistik untuk jangka waktu yang panjang (biasanya dekade atau lebih). Menurut Künzler (2010) perubahan iklim ini memiliki dampak sosialekonomi dan lingkungan yang sangat berat. Ratusan juta orang menderita karena kekurangan air, banjir di area rendah dan pinggir pantai, gelombang panas, kemarau, dan peningkatan penyakit jantung-pernafasan dan infeksi disebabkan perubahan iklim. Disamping itu, ribuan spesies akan mati dan hasil pertanian dapat menurun secara drastis di beberapa wilayah. 


\section{METODE}

Kajian disusun sebagai studi literatur dengan analisis deskriptif dari beragam literatur yang terkait dengan isu-isu perubahan iklim dan aktivitas LSM Lingkungan, serta komunikasi yang terjalin antar para pemangku kepentingan adaptasi dan mitigasi perubahan iklim di Indonesia.

\section{ANALISIS DAN PEMBAHASAN}

\section{Posisi Indonesia Terkait Perubahan Iklim}

Pengertian perubahan iklim menegaskan bahwa perubahan iklim bukanlah kondisi yang baru terjadi dan dirasakan. Fenomena ini menjadi penting setelah disadari bahwa berbagai aktivitas manusia dalam pembangunan ekonomi selama ini yang merubah tata guna lahan dan memproduksi 'gas rumah kaca' telah merubah komposisi atmosfer. Pembakaran besar-besaran batu bara, minyak bumi, kayu, pembabatan hutan, serta penggunaan gas-gas tertentu telah mendorong terjadinya pemanasan di bumi dan atmosfer. Selanjutnya, pemanasan tersebut menyebabkan perubahan iklim yang cenderung ekstrim yang berdampak serius terhadap kehidupan manusia secara global.

Berdasarkan dimensi waktu dan pembangunan tersebut, maka dapat diketahui bahwa negara-negara maju lebih banyak membuang gas-gas rumah kaca dalam jumlah besar ke atmosfer. Terutama karena negaranegara maju telah lama merdeka dan membangun, menerapkan industrialisasi, atau bahkan terlibat dalam peperangan antar negara sehingga membakar lebih banyak bahan bakar fosil. Kemunculan negara-negara baru selanjutnya menambahkan keluaran emisi gasgas rumah kaca ini sejak meraih kemerdekaaan dan mulai membangun. Sejak itu sampai saat ini, emisi tiap negara memicu krisis lingkungan hidup dunia yang menurut KLH (2014) karena berpotensi merubah intensitas badai tropis; pola hujan, salinitas air laut, dan pola angin; masa reproduksi atau daur hidup spesies tertentu seperti nyamuk; musim berbuah atau berbunga spesies tanaman tertentu; distribusi spesies dan ukuran populasi; serta frekuensi serangan hama dan wabah penyakit.

Dengan demikian, secara kronologis, status sebagai negara berkembang pada dasarnya memosisikan Indonesia sebagai negara yang tidak seharusnya menanggung lebih banyak beban untuk mengatasi masalah perubahan iklim. Akan tetapi kenyataan menunjukkan bahwa seluruh warga dunia terkena dampak negatif perubahan iklim global, terlepas dari seberapa banyak setiap negara memproduksi gas-gas rumah kaca. Selain itu, berdasarkan potensi perubahan yang ditimbulkannya, kondisi geografis dan demografis Indonesia menjadikannya sebagai salah satu negara yang rentan terhadap dampak negatif perubahan iklim.

\section{Adaptasi Perubahan Iklim di Indonesia}

Sebagai negara kepulauan, Indonesia sangat rentan terhadap dampak perubahan iklim. Kajian IPCC meramalkan Indonesia akan mengalami kenaikan suhu 1,8 sampai 4 derajat Celsius pada tahun 2050. Dinyatakan bahwa peningkatan suhu global dapat meningkatkan tinggi air laut antara 0,18 hingga 0,59 meter sekitar tahun 2100 dibandingkan tahun 19801999. Sedangkan hasil analisa DNPI yang dilakukan dengan skenario kenaikan $50 \mathrm{~cm}$ tinggi muka air laut, maka Indonesia berpotensi kehilangan lahan pertanian seluas 322.091 hektar atau 4,67\%. Lebih lanjut, ada sekitar 40 juta warga Indonesia yang bermukim dalam jarak $10 \mathrm{~m}$ dari garis pesisir yang terancam perubahan naiknya permukaan air laut. Tidak mengherankan apabila Moediarta dan Stalker (2007) menyatakan bahwa Indonesia akan berhadapan dengan cuaca yang makin tidak menentu dan makin ekstrim, dengan berbagai akibat buruknya, terutama yang dapat menimpa masyarakat kita yang paling miskin.

Untuk menghadapi cekaman perubahan iklim tersebut maka pemerintah Indonesia memasukan beberapa pilihan adaptasi ke dalam Rencana Aksi Nasional Mitigasi dan Adaptasi Perubahan Iklim Indonesia yaitu di sektor sumber daya air, pertanian, kehutanan, pesisir/bahari, kesehatan. Pilihan adaptasi yang lain juga tersedia, dan perlu untuk dipertimbangkan (World Bank-Indonesia 2009). Akan tetapi kenyataan menunjukkan bahwa kegiatan adaptasi perubahan iklim di Indonesia masih jauh dari yang diharapkan, utamanya jika merujuk pada pengertian adaptasi perubahan iklim sebagai suatu upaya penyesuaian sistem sosial, sistem alam, dan sistem tata kelola pemerintahan dalam merespon dampak perubahan iklim.

Kondisi ini bisa terlihat dari masih rendahnya pemahaman sebagain besar anggota sistem sosial atas isu perubahan iklim, semakin maraknya perusakan lingkungan hidup, serta 
masih kurangnya program-program pembangunan yang berperspektif adaptasi perubahan iklim. Oleh sebab itu tidak sedikit wilayah di Indonesia yang sering dilanda musibah-musibah yang diakibatkan oleh berubahnya suhu bumi, musim hujan ekstrim dan kemarau berkepanjangan seperti kerusakan lingkungan pesisir akibat meningkatnya serangan badai dan gelombang laut, banjir dan tanah longsor, serta kekeringan berkepanjangan.

\section{Menuju Indonesia Adaptif}

Iklim nyata dan perkiraan saat ini pada akhirnya menegaskan bahwa pemerintah sudah harus memberikan perhatian lebih sebagai respon atas isu-isu perubahan iklim. Utamanya bukan hanya untuk melindungi kelompokkelompok masyarakat dengan sumber nafkah yang rentan terhadap perubahan iklim ataupun yang memiliki sumber daya terbatas untuk menanggulangi daya rusak dari bencana alam yang muncul sebagai dampak negatifnya, tetapi juga untuk menjamin keberlanjutan pembangunan nasional.

\section{Regulasi Perubahan Iklim}

Satu hal sangat penting yang menjadikan pembangunan nasional rentan secara sosiologis serta politis dalam menghadapi isu perubahan iklim adalah masih kurangnya undang-undang khusus terkait perubahan iklim. Sampai saat ini Indonesia hanya memiliki UU Nomor 32 Tahun 2009 tentang Perlindungan dan Pengelolaan Lingkungan Hidup sebagai peraturan perundangan yang terkait secara spesifik dengan isu perubahan iklim, serta Peraturan Presiden Nomor 61 Tahun 2011 terkait Rencana Aksi Nasional Gas Rumah Kaca (RAN-GRK) yang mencakup 70 program yang terdistribusi di antara sejumlah sektor seperti hutan dan lahan gambut, limbah, pertanian, industri, energi dan transportasi. Kondisi ini tentu dapat menyebabkan keterbatasan akses dalam pendanaan (anggaran) dan teknologi dan selanjutnya akan memengaruhi upaya peningkatan kapasitas adaptasi anggota masyarakat.

Sebagai perbandingan, Meksiko telah memberlakukan UU sebagai panduan segala kebijakan terkait perubahan iklim, Korea Selatan mempunyai legislasi yang mengatur skema perdagangan emisi pada tahun 2015, sedangkan pemerintah Jerman telah memiliki Rencana Aksi Adaptasi Perubahan Iklim yang mengatur tanggung jawab Jerman di tingkat internasional, inisiatif pemerintah untuk membangun basis pengetahuan dan menyediakan informasi, penyediaan insentif dan kerangka legal bagi proyek adaptasi, serta konstruksi berkelanjutan bagi gedung-gedung pemerintah.

Terlihat jelas bahwa regulasi-regulasi terkait adaptasi perubahan iklim yang sudah dikeluarkan pada dasarnya belum merujuk pada satu regulasi induk kegiatan adaptasi perubahan iklim yang secara hukum mengikat dan mengatur seluruh pihak. Seperti beberapa kementerian sudah menjadikan isu perubahan iklim sebagai mainstream karena memang target program-program kebijakan yang sudah direncanakan cukup terancam oleh perubahan iklim, serta kalangan industri yang mulai memerhatikan tata kelola lingkungan hidup. Akan tetapi pendekatan seperti ini menjadi tidak efektif karena regulasi-regulasi yang dirujuk justru memperkuat pendekatan pembangunan yang lebih bersifat sektoral, belum lagi kebijakan-kebijakan yang dihasilkannya dapat berubah seiring pergantian pemerintahan.

Dengan demikian kebijakan pembangunan nasional yang berperspektif adaptasi perubahan iklim merupakan strategi yang diperlukan untuk mencapai pembangunan berkelanjutan dalam jangka panjang. Persoalan yang kemudian dihadapi adalah bagaimana menyusun kebijakan pembangunan untuk masa datang tetapi bisa ditetapkan oleh pemerintah saat ini tanpa harus khawatir akan diubah oleh rezim pemerintah berikutnya. Persoalan tersebut bisa terjawab jika terdapat instrumen pengikat yang memiliki daya jangkau yang lebih panjang dan luas dalam mengintegrasikan kegiatan-kegiatan adaptasi perubahan iklim dalam setiap kebijakan pembangunan nasional.

Oleh sebab itu, sudah saatnya Indoonesia memiliki undang-undang khusus yang secara spesifik mengatur segala hal terkait perubahan iklim. Keberadaan UU Perubahan iklim tersebut selain menunjukkan respon lebih serius dan terukur dari pemerintah atas isu-isu perubahan iklim global, juga akan menjadi instrumen guna terintegrasinya kegiatan adaptasi perubahan iklim dalam setiap agenda pembangunan nasional, menjadi rujukan setiap para pihak, dan meningkatkan akselerasi pengembangan perilaku adaptif yang dapat 
meningkatkan daya tahan anggota masyarakat terhadap dampak negatif perubahan iklim.

\section{Peran LSM Lingkungan}

Beberapa kegiatan yang dilakukan LSMLSM Lingkungan di Indonesia dalam mendorong pengesahan UU Perubahan Iklim diantaranya adalah pernyataan LSM Lingkungan kepada media terkait pentingnya satu undang-undang tentang penanggulangan perubahan iklim nasional, dimana didalamnya menetapkan target penurunan emisi nasional serta mengatur upaya mitigasi dan adaptasi perubahan iklim. Pernyataan tersebut merespon Keputusan Presiden No. 5 tahun 2013 yang poin utamanya adalah memperpanjang masa tugas Satuan Tugas Persiapan Kelembagaan REDD+ (Satgas REDD+) yang menurut kalangan LSM Lingkungan semakin mempersempit upaya-upaya penurunan emisi (antaranews.com). Juga dengan mengadakan Pawai Iklim Masal di depan Gedung UOB Plaza Jakarta saat berlangsungnya kegiatan $\mathrm{Car}$ Free Day yang menampilkan baliho presiden Joko Widodo dengan teks-teks yang merespon isu-isu perubahan iklim untuk pembangunan berkelanjutan (harian terbit.com).

Untuk mengawal RUU Perubahan Iklim, LSM-LSM Lingkungan juga menyelenggarakan seminar, workshop dan FGD "Perubahan Iklim" bersama politisi dan akademisi di banyak wilayah seperti Padang, Lampung, Banten, Jakarta, Bandung, Cirebon, Semarang, Yogyakarta, Surabaya, Malang, Makasar, Manado, NNT, NTB dan beberapa kota besar lainnya. Agenda yang diusung adalah kampanye nilai-nilai perubahan iklim dan pembangunan berkelanjutan. Kegiatan seperti ini bertujuan untuk membangun sinergi dengan akademisi sehingga rancangan naskah akademik dan kajian terkait RUU Perubahan Iklim sudah kuat sebelum sampai di tangan para politisi dalam parlemen (FNF Indonesia 2015).

Selain itu, melalui dialog yang dihadiri perwakilan MUI, Walubi, Persekutuan Gereja Indonesia (PGI), Konferensi Waligereja Indonesia (KWI), Parisada Hindu Dharma Indonesia (PHDI), Muhammadiyah, serta WWF-Indonesia, para tokoh lintas agama yang terafiliasi dengan CDCC sepakat melakukan gerakan nasional penyelamatan bumi dari ancaman perubahan iklim akibat peningkatan emisi gas rumah kaca (GRK) secara global. Gerakan nasional yang ingin dilakukan lebih kepada aksi nyata memberikan advokasi, edukasi, kampanye, sosialisasi kepada seluruh lapisan masyarakat agar peduli dengan kondisi lingkungan dan paham tentang bahaya peningkatan suhu bumi. Termasuk akan "menyerempet" ke ranah politik jika memang diperlukan, yaitu dengan memberikan usulan perubahan undang-undang yang dianggap memicu kerusakan lingkungan (antaranews.com).

\section{Strategi Komunikasi LSM Lingkungan}

Berdasarkan beberapa kegiatan LSMLSM Lingkungan tersebut dapat diketahui bahwa LSM Lingkungan telah bertindak sebagai aktor politik yang mencoba menjalin komunikasi politik dengan aktor politik lainnya yaitu para politisi dan pemerintah. Tujuannya adalah untuk membentuk opini publik terkait pentingnya pengesahan UU Perubahan Iklim. Kondisi ini menunjukkan penilaian LSM-LSM Lingkungan atas lemahnya perencanaan perubahan sosial (pembangunan) dari pemerintah dalam merespon perubahan iklim global. Langkah seperti ini menurut kesimpulan McPhail (2009) tentang LSM merupakan pertanda positif bagi tujuan pembangunan, demokratisasi, dan upaya peningkatan kualitas hidup jutaan orang di seluruh dunia dapat tercapai.

Selama ini komunikasi politik pemerintah sebagai perencana perubahan sosial (pembangunan) dalam merespon isu-isu perubahan iklim memang cenderung kurang efektif, terutama jika dilihat dari lemahnya efek yang dihasilkan dari komunikasi politik tersebut yaitu masih kurangnya regulasi perubahan iklim yang dihasilkan serta belum berkembangnya perilaku adaptif di tengah-tengah masyarakat. Jika ditelisik, kondisi di atas ditambah dengan kesadaran kesamaan hak (demokratisasi) untuk kehidupan yang lebih baik inilah yang kemudian mendorong kalangan LSM Lingkungan (sebagai aktor politik) menjalin komunikasi politik dan memotori terjadinya perubahan sosial (gerakan sosial) untuk merespon fenomena perubahan iklim.

Status dan peran ini sesuai dengan pendapat McNair (2003) yang mengkategorikan LSM sebagai aktor politik karena merupakan salah satu bentuk organisasi publik independen, sehingga menjadi salah satu elemen komunikasi politik. Seperti halnya partai dan organisasi publik, LSM menggunakan bermacam teknik 
periklanan dan PR yang saat ini tersedia untuk berkomunikasi. Dalam konteks ini, terlihat bahwa strategi komunikasi berikutnya dari LSM Lingkungan di Indonesia dalam mengkomunikasikan isu-isu perubahan iklim kepada para pihak adalah dengan mengoptimalkan pemanfaatan seluruh saluran komunikasi. Strategi ini sejalan dengan apa yang disimpulkan McPhail (2009) bahwa salah satu kunci keberhasilan LSM adalah mendapatkan perhatian dari media massa.

Menampilkan baliho Presiden Joko Widodo dalam kegiatan car free day serta pelibatan toko-tokoh agama merupakan strategi yang tepat dari LSM Lingkungan dalam mengkampanyekan isu-isu perubahan iklim serta mendorong lahirnya UU Perubahhan Iklim. Seperti yang diutarakan Nimmo (1999) bahwa para pemuka pendapat merupakan saluran yang menghubungkan jaringan massa dan komunikasi interpersonal. Pemuka pendapat yaitu orang yang menaruh perhatian terhadap media massa, memilih pesan, dan menyampaikan informasi serta opini baik kepada teman, tetangga, maupun kawan bekerja dan lainnya melalui percakapan tatap muka. Dengan demikian, selain memberikan pengaruh mereka terhadap keputusan politik secara interpersonal, para pemuka pendapat juga sangat berperan dalam penyebaran informasi politik.

Sebagai komunikator politik, LSM-LSM Lingkungan mencoba meletakkan isu adaptasi perubahan iklim sebagai basis di dalam pertumbuhan ekonomi dan sosial. Melalui cara ini, mereka menyampaikan pesan bahwa keberlanjutan pembangunan ekonomi, sosial, dan budaya oleh negara untuk sebesar-besarnya kemakmuran rakyat baru akan terjamin jika pemerintah merespon isu-isu perubahan iklim global secara serius. Indonesia akan mengalami keterpurukan jika tidak mampu mengelola lingkungan hidupnya karena akan kehilangan daya dukung atas aktivitas ekonominya untuk mempertahankan kehidupan seluruh anggota masyarakat.

Pemanfaatan saluran komunikasi massa (koran) termasuk juga media yang lebih independen (web, blog, on-line, situs) dan jaringan komunikasi politik (politisi dan akademisi) menunjukan bahwa LSM Lingkungan bukan hanya menjadikan media sebagai alat untuk menyampaikan pesan persuasif perubahan iklim kepada khalayak, tetapi juga menjadikan media massa sebagai pusat komunikasi (ruang publik) yang dapat mendorong partisipasi politik masyarakat dalam merespon isu-isu perubahan iklim termasuk respon dari media itu sendiri. Seperti yang diutarakan McNair (2003) bahwa media atau praktisinya merupakan aktor politik yang memiliki peran penting karena tidak hanya mengirimkan pesan politik kepada publik, tetapi juga mengubah pesan politik tersebut atau membuat pernyataan tentang politik dalam bentuk komentar, editorial dan pertanyaan wawancara yang mungkin memiliki dampak signifikan pada lingkungan politik yang lebih luas.

Strategi komunikasi LSM Lingkungan di Indonesia ini sesuai dengan kesimpulan penelitian Padgamn dkk (2013) bahwa penggunaan alat dan metode untuk komunikasi resiko iklim yang bervariasi dan kreatif penting sekali untuk mencapai berbagai kelompok pemangku kepantingan. Selanjutnya dijelaskan bahwa penekanan pada pembangunan partisipatif dari alat dan metode komunikasi risiko iklim menciptakan rasa memiliki yang lebih besar dari para pemangku kepentingan dan lebih mungkin memicu pembelajaran serta meningkatkan kapasitas tindakan dibandingkan dengan strategi komunikasi risiko yang mengandalkan pendekatan top-down untuk penyampaian informasi tentang perubahan iklim. Selain itu juga diperkuat oleh pandangan Khor, Direktur Eksekutif South Centre (organisasi antarpemerintah) yang lama aktif sebagai anggota LSM, bahwa kunci sukses LSM adalah mengangkat banyak kasus ke permukaan melalui media, termasuk media sosial yang menjadi wahana untuk semua orang berkomentar bebas. Media memiliki peran besar karena semua orang membaca media. Kalau sentimen publik terbangun, pemerintah akan memberikan respons. Walaupun perubahan yang terjadi bergantung pada visi pemerintah, visi masyarakat sipil, serta editor media, tetapi jika tidak ada yang menulis maka tidak akan ada tekanan (Kompas 2016).

\section{SIMPULAN}

Masih tingginya cekaman dampak negatif perubahan iklim dan rendahnya perilaku adaptif sebagian besar anggota masyarakat di Indonesia disebabkan oleh belum adanya regulasi pokok yang mampu mengintegrasikan 
perspektif perubahan iklim ke dalam setiap program-program pembangunan nasional.

LSM-LSM Lingkungan di Indonesia mengkombinasikan strategi komunikasi pembangunan yang didasarkaan pada media yang dipakai dan strategi komunikasi pembangunan partisipatori untuk mendorong lahirnya UU Perubahan Iklim. Pemanfaatan saluran komunikasi interpersonal dan komunikasi massa bertujuan untuk mengoptimalkan penyampaian pesan secara persuasif kepada masyarakat akan pentingnya perilaku adaptif terhadap perubahan iklim, serta untuk membuka ruang publik yang dapat memicu partisipasi anggota masyarakat dalam mendorong lahirnya UU Perubahan Iklim.

Belum disahkannya UU Perubahan Iklim mengindikasikan belum tercapainya efek yang diharapkan dari komunikasi politik yang dijalin oleh LSM-LSM Lingkungan. Kenyataan ini akan memengaruhi pencapaian tujuan dan keberlanjutan dari pembangunan nasional.

\section{SARAN}

Lahirnya UU Perubahan Iklim sangat bergantung pada kesamaan persepsi para pihak yang belum memiliki pengalaman langsung terkait isu-isu perubahan iklim. Untuk itu sudah seharusnya LSM-LSM Lingkungan tidak hanya membuka ruang partisipasi publik secara sepihak, tetapi juga mendorong pemerintah untuk bersama-sama membuka ruang partisipasi publik yang lebih luas dan memberi waktu yang lebih panjang untuk terjalinnya komunikasi antara para pihak agar segera tercipta konsensus dan rasa memiliki atas UU Perubahan Iklim. Selanjutnya pemerintah sebagai pihak yang berwenang dalam proses legislasi harus memfasilitasi pengesahannya dengan agenda yang jelas dan setiap agenda memiliki target yang terukur.

\section{DAFTAR PUSTAKA}

Arundhati ST, Wibowo A, Widayati T, Wijanarka K, Suryanti Y, Widyarissantie A, Sugiatmo, Kusmulyani, Mardiah SN. 2014. Upaya Praktis Adaptasi Perubahan Iklim. Kementerian LH Deputi Bidang Pengendalian Kerusakan Lingkungan dan Perubahan Iklim. Jakarta.

Bernauer, Thomas. 2013. Climate Change Politics. Center for Comparative and International Studies and Institute for
Environmental Decisions. ETH Zurich, CH-8092 Zurich. Switzerland

IPCC, 2007: Climate Change 2007: Synthesis Report. Contribution of Working Groups I, II and III to the Fourth Assessment Report of the Intergovernmental Panel on Climate Change [Core Writing Team, Pachauri, R.K and Reisinger, A. (eds.)]. IPCC, Geneva, Switzerland.

KLH (2014). Upaya Praktis Hadapi Perubahan Iklim. KLH: Deputi Bidang Pengendalian Kerusakan Lingkungan dan Perubahan Iklim. Jakarta

Künzle, Marion. 2010. Perubahan Iklim di Indonesia. Brot für alle -Pain pour le prochain - Bread for All. Bern Swiss; Swiss Postfach 5621 CH-3001

Leeuwis, Cees. 2004. Komunikasi Untuk Inovasi Pedesaan: Berpikir Kembali tentang Penyuluhan Pertanian. Kanisius. Jogjakarta

McNair, Brian. 2003. An Introduction to Political Communication: Third Edition. London. Routledge.

McPhail Thomas L. 2009. Development Communication: Reframing The Role of The Media. Edition First. UK: Blackwell

Nasution, Zulkarimein. 2002. Komunikasi Pembangunan, Pengenalan Teori dan Penerapannya. Jakarta : PT RajaGrafindo Persada.

Nimmo, Dan. 1989. Komunikasi Politik. Komunikator, Pesan dan Media.

Remaja Rosda Karya. Bandung

Moediarta R dan Stalker P. 2007. Sisi lain perubahan iklim: Mengapa Indonesia harus beradaptasi untuk melindungi rakyat miskinnya. UNDP Indonesia Country Office. Jakarta

Jon Padgham, Tahia Devisscher, Chuluun Togtokh, Lucy Mtilatila, Ethel Kaimila, Indira Mansingh, Francis AgyemangYeboah, Francis K. Obeng. 2013. Membangun Pemahaman dan Kapasitas Bersama untuk Aksi: Wawasan atas komunikasi resiko iklim di India, Ghana, Malawi, Mongolia. ijoc.org/index.php/ijoc/article/view/1475

Sekretariat Negara Republik Indonesia. 2009. UU Nomor 32 Tahun 2009 tentang Perlindungan dan Pengelolaan Lingkungan Hidup. Jakarta 
World Bank. 2009. Adaptasi terhadap Perubahan Iklim. Policy Brief. Kantor Bank Dunia. Jakarta

Sumber media cetak:

Indonesia Climate Action Network (ICAN) 2013. "Laporan IPCC: Perubahan Iklim Nyata, Umat Manusia Menghadapi Ancaman Serius". Siaran Pers

Martin Khor. 2016. "Media Memiliki Peran Besar". Rubrik Tokoh. Harian Kompas

Sumber media on-line:

http://www.fnf-indonesia.org/focus-groupdiscussion-mengenai-masalahperubahan-iklim-di-samarinda-25agustus-2015/

http://www.antaranews.com/print/355606/indon esia-perlu-uu-perubahan-iklim

http://www.harianterbit.com/2015/read/2014/09 /21/8650/29/29/Walhi-DesakPemerintah-dan-DPR-Buat-UUPerubahan-Iklim 